\title{
Hubungan Laju Alir dan Viskositas Saliva dengan Tingkat Kecekatan Gigi Tiruan Penuh pada Pasien Rumah Sakit Gigi dan Mulut Universitas Andalas
}

Sevty Agustin ${ }^{1}$, Eni Rahmi ${ }^{1}$, Arymbi Pujiastuty ${ }^{1}$

Korespondensi : Eni Rahmi; eni.rahmi@dent.unand.ac.id; Telp: 081377530409

\begin{abstract}
The most common complaint reported by patients in denture wearing is loose denture, caused by lack of retention. In the complete denture wearing, saliva plays an important role in retention. A well-fitting denture base to supporting tissues and the presence of adequate border seals will provide optimal denture retention. This condition can be achieved if it is supported by adequate volume, flow, and consistency of saliva. The purpose of this study is to determine the relationship between flow rate and viscosity of saliva with complete denture retention in Andalas Dental Collage and Hospital. This study used a cross sectional design. Thirty patients of complete denture wearers at the Andalas Dental Collage and Hospital were included in this study. Samples were selected through consecutive sampling method. Data were collected by using medical records, saliva viscosity assesstment, salivary flow rate measurement, and complete denture retention examination. Data were analyzed by Mann Whitney tes with $p<0,05$. There was a significant relationship between salivary flow rate and maxillary complete denture retention $(p=0,002)$ and there was a significant relationship between saliva viscosity and maxillary complete denture retention $(p=0,002)$. However there was no relationship between salivary flow rate and mandibular complete denture retention $(p=0.101)$ and there was no relationship between saliva viscosity and mandibular complete denture retention $(p=0,223)$. The conclusion of this study was that the flow rate and viscosity of saliva was associated with maxillary complete denture retention yet was not associated with mandibular denture retention.
\end{abstract}

Key words: complete denture; salivary flow rate; saliva viscosity; retention

Affiliasi penulis : 1. Fakultas Kedokteran Gigi, Universitas Andalas

\section{PENDAHULUAN}

Gigi tiruan penuh (GTP) merupakan salah satu perawatan yang sangat lazim bagi individu yang kehilangan gigi seluruhnya. GTP lepasan adalah protesa yang dapat dilepas pasang oleh pasien dan bertujuan untuk memperbaiki estetika, fungsi mastikasi, fungsi fonetik, dan melindungi jaringan pendukung di bawah GTP. ${ }^{1}$ Perawatan prostodontik berupa pembuatan gigi tiruan untuk menggantikan gigi yang hilang sangat diperlukan bagi pasien dengan kehilangan gigi sebagian atau seluruhnya. Indonesia memiliki prevalensi kehilangan gigi sebesar $1,3 \%$ pada penduduk umur $\geq 12$ tahun menurut karakteristik dengan persentase tertinggi terjadi pada umur 65 tahun ke atas, yaitu sebesar 9,0\%. ${ }^{2}$ Prevalensi kehilangan gigi di Sumatera Barat sebesar 2,4\% dengan persentase tertinggi pada umur 65 tahun keatas, yaitu sebesar $9,8 \% .^{3}$

Permintaan terhadap perawatan gigi tiruan penuh di Amerika Serikat meningkat meskipun prevalensi kehilangan gigi terus berkurang pada usia dewasa. Prevalensi penggunaan gigi tiruan penuh di Indonesia pada penduduk umur $\geq 12$ tahun menurut karakteristik sebesar $1,2 \%$, lebih sedikit dibanding 
prevalensi kehilangan giginya. ${ }^{2}$ Prevalensi penggunaan gigi palsu di Sumatera Barat sebesar 1,5\% dengan persentase tertinggi pada kelompok usia 65 tahun ke atas sebesar $5,8 \%{ }^{3}$

Masalah yang sering dikeluhkan pasien pasca insersi gigi tiruan penuh adalah iritasi pada mukosa, gigi tiruan terasa longgar, akumulasi sisa makanan di bawah gigi tiruan, kesulitan berbicara, kesulitan mengunyah, penampilan yang tidak menarik, dan gigi tiruan patah. Salah satu masalah pemakaian gigi tiruan penuh yang menjadi keluhan utama pasien adalah gigi tiruan yang terasa longgar yang disebabkan oleh kurangnya retensi dan stabilitas gigi tiruan. ${ }^{4}$ Pemakaian gigi tiruan yang tidak cekat dapat mengakibatkan nyeri dan trauma pada mukosa yang menyebabkan denture stomatitis. ${ }^{5}$

Pada pemakaian gigi tiruan, saliva mempunyai peranan penting terhadap retensi GTP. Kohesi, adhesi, dan tegangan permukaan interfasial merupakan faktor yang mempengaruhi retensi gigi tiruan yang berhubungan dengan saliva. Basis gigi tiruan yang beradaptasi rapat dengan jaringan pendukung dan adanya border seal yang adekuat akan memberikan fungsi gigi tiruan yang optimal. Hal ini dapat dicapai apabila didukung juga oleh volume, aliran, dan konsistensi saliva yang adekuat. ${ }^{6}$

Saliva berperan dalam pembentukan tekanan hampa udara pada dudukan gigi tiruan dan berkontribusi secara signifikan terhadap retensi gigi tiruan dan kepuasan pasien terhadap pemakaian gigi tiruan. ${ }^{6}$ Saliva dengan konsistensi kental dan lengket akan terakumulasi diantara basis GTP dan mukosa dibawahnya mengakibatkan hilangnya retensi GTP, saliva yang terlalu encer juga mengakibatkan kurangnya retensi GTP.7 Sebuah penelitian menunjukkan adanya korelasi positif antara kecekatan GTP rahang atas dengan komponen fisik dan biokimia saliva, yaitu dua dari beberapa parameter yang diukur adalah laju alir dan viskositas saliva. ${ }^{8}$

\section{METODE}

Penelitian ini merupakan merupakan penelitian observational analitic dengan desain cross sectional. Penelitian dilaksanakan pada bulan Juni - Juli 2019. Teknik pengambilan sampel dalam penelitian ini menggunakan teknik consecutive sampling. Sampel dalam penelitian ini adalah 30 orang pasien perawatan GTP Rumah Sakit Gigi dan Mulut (RSGM) Universitas Andalas tahun 2018-2019. Sampel dipilih berdasarkan kriteria inklusi dan ekslusi yang didapatkan melalui skrining dan pemeriksaan kecekatan GTP. Pemeriksaan dilakukan dengan cara menginstruksikan pasien untuk melakukan gerakan fungsional seperti membuka tutup mulut, menggerakkan lidah, dan operator menarik mukosa bukal dan labial pasien. Pengukuran tinggi lingir rahang bawah pasien dengan melakukan rontgen panoramik yang bertujuan untuk menyamakan tinggi lingir alveolar rahang bawah yaitu sebesar $\geq 21 \mathrm{~mm}$, dikategorikan sebagai klas I (baik) berdasarkan American College of Prosthodontics.

Sampel yang sudah memenuhi kriteria kemudian diminta persetujuannya dengan mengisi informed consent. Selanjutnya dilakukan pengumpulan saliva untuk menilai viskositas dan laju alir saliva serta pemeriksaan kecekatan GTP menggunakan neraca digital yang dimodifikasi. Penilaian viskositas dilakukan secara visual dan dikategorikan berdasarkan GC Saliva Check Buffer Kit, sedangkan laju alir saliva dilakukan dengan metode spitting. Data yang didapatkan dianalisis menggunakan uji analisis statistik Mann Whitney. 


\section{HASIL DAN PEMBAHASAN}

\section{Karakteristik sampel penelitian}

Karakteristik sampel diperoleh setelah dilakukan pengumpulan data dengan menggunakan lembar screening sebanyak 30 pasien RSGM Universitas Andalas sebagai responden penelitian. Hasil penelitian menunjukkan sebagian besar responden berjenis kelamin perempuan yaitu sebanyak 17 orang (57\%) dan usia responden paling banyak berada pada usia kurang dan sama dengan 65 tahun yaitu sebanyak 22 orang (73\%). Pada penelitian ini jumlah responden GTP berjenis kelamin perempuan lebih banyak dibandingkan laki-laki. Keadaan ini dapat dikaitkan dengan perhatian perempuan yang tinggi terhadap penampilan sehingga lebih banyak perempuan yang membutuhkan GTP. Hasil penelitian Singh dkk (2012) mengenai tingkat keinginan sampel terhadap perawatan GTP berdasarkan jenis kelamin, menunjukkan bahwa wanita lebih termotivasi untuk melakukan perawatan GTP dibandingkan laki-laki. Hal ini dikarenakan wanita lebih sadar dan perhatian terhadap perawatan GTP untuk mengembalikan fungsi estetik, fungsi bicara, dan kesejahteraan sosial mereka. ${ }^{9}$

\section{Gambaran Laju Alir dan Viskositas Saliva}

Hasil penelitian menunjukkan bahwa pada pasien perawatan GTP RSGM Universitas Andalas paling banyak memiliki laju alir saliva normal yaitu sebanyak 18 orang (60\%) dan viskositas saliva normal yaitu sebanyak 21 orang (70\%). Hasil penelitian menunjukkan bahwa laju alir saliva pada kedua kelompok pasien perawatan GTP RSGM Universitas Andalas berjenis kelamin laki-laki dan perempuan relatif normal yaitu pada laki laki sebesar 69,2\% dan perempuan sebesar 52,9\%. Laju alir saliva pasien perawatan GTP RSGM Universitas Andalas pada usia $\leq 65$ tahun sebagian besar memiliki laju alir normal $(54,5 \%)$ dan usia > 65 tahun sebagian besar memiliki laju alir saliva normal (75\%).

Viskositas saliva pada kedua kelompok pasien perawatan GTP RSGM Universitas Andalas berjenis kelamin laki-laki dan perempuan relatif normal yaitu pada laki laki sebesar $69,2 \%$ dan perempuan sebesar 70,6\%. Berdasarkan tabel 4 dapat dilihat bahwa viskositas saliva pasien perawatan GTP RSGM Universitas Andalas pada usia $\leq 65$ tahun sebagian besar memiliki viskositas saliva normal $(68,2 \%)$ dan usia > 65 tahun sebagian besar memiliki viskositas saliva normal (75\%).

Sekresi saliva dipengaruhi oleh beberapa faktor seperti stres, kecemasan, depresi, usia, obatobatan, dan faktor-faktor yang lain. Kondisi lain seperti dehidrasi, anoreksia, bulimia, dan gangguan makan seperti defisiensi nutrisi dapat menyebabkan perubahan metabolisme yang berhubungan dengan penurunan sekresi. ${ }^{10}$ Pertambahan usia juga mempengaruhi sekresi saliva. Secara histologi, dengan semakin bertambahnya usia sel-sel parenkim pada kelenjar saliva akan terus tergantikan oleh sel-sel adiposa dan jaringan fibrovaskular, dan volume dari sel-sel asinar akan berkurang. ${ }^{11}$ Penelitian Nassar dkk (2013) menyimpulkan bahwa pertambahan usia mempengaruhi laju alir saliva pada individu yang sehat secara sistemik. ${ }^{12}$ Penelitian ini tidak bertujuan untuk mencatat kondisi sistemik yang mempengaruhi saliva seperti obat-obatan, kondisi psikologis atau penyakit yang mempengaruhi sekresi saliva pasien sehingga persamaan proporsi laju alir dan viskositas saliva pada kelompok jenis kelamin pria dan wanita serta pada usia $\leq 65$ tahun dan > 65 tahun tidak dapat dijelaskan pada penelitian ini. 
Hasil penelitian menunjukkan bahwa pada GTP rahang atas pasien RSGM Universitas Andalas paling banyak ditemukan kecekatan maksimum yaitu sebanyak 16 orang $(53,3 \%)$. Berbanding terbalik dengan GTP rahang atas, gambaran tingkat kecekatan GTP rahang bawah pada pasien RSGM Universitas Andalas paling banyak ditemukan tingkat kecekatan minimum yaitu sebanyak $21(70,0 \%)$ orang. Hasil penelitian ini diperkuat dengan mayoritas responden mengeluhkan GTP rahang bawah terasa longgar. Hasil penelitian Sikander dkk (2016) melaporkan bahwa 60\% pasien pengguna GTP yang dibuatkan oleh mahasiswa klinik di Islamic International Dental College di Pakistan mengeluhkan GTP yang longgar dan mayoritas adalah GTP rahang bawah. ${ }^{13}$ Limpuangthip dkk (2019) meneliti mengenai hubungan tingkat kecekatan dan stabilitas GTP dengan kualitas hidup seseorang. Pada penelitiannya diketahui bahwa GTP rahang atas lebih retentif dibandingkan GTP rahang bawah. ${ }^{14}$

Beberapa faktor penting yang berperan terhadap kecekatan GTP adalah terbentuknya kontak yang rapat dan akurat basis GTP terhadap mukosa dibawahnya serta adanya peripheral seal yang baik. ${ }^{15}$ Hilangnya fungsi peripheral seal paling sering terjadi pada GTP rahang bawah di bagian anterior sulkus alveololingual. Hal ini terjadi karena hilangnya kontak antara tepi GTP rahang bawah dengan jaringan dasar mulut dan pergerakan lidah yang mengakibatkan kehilangan fungsi lingual border seal, sehingga mengakibatkan GTP rahang bawah kurang retentive. ${ }^{16}$

Hal ini juga dapat dikaitkan dengan atropi pada mandibula yang terjadi lebih cepat dibandingkan rahang atas sehingga memberikan dampak berkurangnya retensi GTP. Teknik penyusunan gigi geligi serta memposisikan basis GTP pada posisi neutral zone adalah teknik paling efektif untuk menghindari GTP rahang bawah menjadi tidak retentif. Apabila hal ini dapat dicapai maka tekanan dari gerakan otototot bukal, bibir dan lidah pada saat gerakan mengunyah, menelan, dan berbicara menjadi seimbang. Hal ini dapat membantu GTP rahang bawah menjadi lebih stabil dan retentive. ${ }^{17}$

\section{Hubungan Laju Alir dan Viskositas Saliva Dengan Tingkat Kecekatan GTP Rahang Atas Pada Pasien Perawatan GTP RSGM Universitas Andalas}

Tabel 1. Hubungan Laju Alir Saliva Dengan Tingkat Kecekatan GTP Rahang Atas Pada Pasien

Perawatan GTP RSGM Universitas Andalas Tahun 2018-2019

\begin{tabular}{lccccccccc}
\hline & \multicolumn{7}{c}{ Tingkat Kecekatan GTP rahang atas } \\
\cline { 2 - 8 } Laju Alir Saliva & \multicolumn{2}{c}{ Minimum } & \multicolumn{2}{c}{ Sedang } & \multicolumn{2}{c}{ Maksimum } & \multicolumn{2}{c}{ Total } & \\
\cline { 2 - 8 } & $\mathrm{N}$ & $\%$ & $\mathrm{~N}$ & $\%$ & $\mathrm{~N}$ & $\%$ & $\mathrm{~N}$ & $\%$ & \\
\hline Hiposalivasi + rendah & 5 & 45,5 & 4 & 36,4 & 2 & 18,2 & 11 & 100 \\
Normal & 1 & 5,3 & 4 & 21,1 & 14 & 73,7 & 19 & 100 & 0,002 \\
\hline Total & 6 & 20,0 & 8 & 26,7 & 16 & 53,3 & 30 & 100 & \\
\hline
\end{tabular}


Fakultas Kedokteran Gigi Universitas Andalas

Jalan Perintis Kemerdekaan No. 77 Padang, Sumatera Barat

Web: adj.fkg.unand.ac.id Email: adj@dent.unand.ac.id

Tabel 2. Hubungan Viskositas Saliva Dengan Tingkat Kecekatan GTP Rahang Atas Pada Pasien

Perawatan GTP RSGM Universitas Andalas Tahun 2018-2019

\begin{tabular}{lccccccccc}
\hline \multirow{2}{*}{ Viskositas Saliva } & \multicolumn{8}{c}{ Tingkat Kecekatan GTP rahang atas } \\
\cline { 2 - 8 } & \multicolumn{2}{c}{ Minimum } & \multicolumn{2}{c}{ Sedang } & \multicolumn{2}{c}{ Maksimum } & \multicolumn{2}{c}{ Total } & \\
\cline { 2 - 8 } & $\mathrm{N}$ & $\%$ & $\mathrm{~N}$ & $\%$ & $\mathrm{~N}$ & $\%$ & $\mathrm{~N}$ & $\%$ & \\
\hline Sangat tinggi + tinggi & 6 & 66,7 & 2 & 22,2 & 1 & 11,1 & 9 & 100 & \\
Normal & 0 & 0 & 6 & 28,6 & 15 & 71,4 & 21 & 100 & 0,002 \\
\hline Total & 6 & 20,0 & 8 & 26,7 & 16 & 53,3 & 30 & 100 & \\
\hline
\end{tabular}

Hasil penelitian menunjukkan bahwa hasil uji statistik hubungan laju alir saliva dengan tingkat kecekatan GTP rahang atas pada pasien RSGM Universitas Andalas diperoleh nilai $p=0,002(p<0,05)$. Kesimpulan yang dapat ditarik dari data tersebut adalah terdapat hubungan yang bermakna antara laju alir saliva dengan tingkat kecekatan GTP pada pasien RSGM Universitas Andalas. Hasil uji statistik untuk hubungan viskositas saliva dengan tingkat kecekatan GTP rahang atas pada pasien RSGM Universitas Andalas diperoleh nilai $p=0,002(p<0,05)$. Kesimpulan yang dapat ditarik dari data tersebut adalah terdapat hubungan yang bermakna antara viskositas saliva dengan tingkat kecekatan GTP pada pasien RSGM Universitas Andalas.

Veeraiyan (2017) menyatakan bahwa faktor fisik yang mempengaruhi retensi GTP adalah adhesi, kohesi, gaya kapilaritas, tegangan permukaan interfasial, dan tekanan atmosfer. Faktor-faktor tersebut dipengaruhi oleh lapisan tipis saliva diantara mukosa dan basis gigi tiruan. ${ }^{7}$ Viskositas saliva membantu dalam mencegah lepasnya GTP sehingga menjadi faktor penting dalam retensi GTP dan berperan sebagai natural adhesive GTP.

Hasil hipotesis ini sejalan dengan penelitian oleh Taqa dkk (2018) yang mengevaluasi komponen fisik dan biokimia saliva yang berhubungan dengan kecekatan GTP. Hasil penelitiannya menunjukkan adanya korelasi positif antara kecekatan GTP rahang atas dengan komponen fisik dan biokimia saliva, yaitu dua dari beberapa parameter yang diukur adalah laju alir dan viskositas saliva. ${ }^{8}$ Hasil penelitian ini juga sejalan dengan penelitian Ostlund (1960) yang melaporkan GTP rahang atas lebih retentif ketika aliran saliva distimulasi dengan obat peningkat laju alir saliva dibandingkan tanpa stimulasi obat. Campbell (1956) melaporkan hasil yang berbeda yang bertentangan dengan hasil penelitian Ostlund. Pada hasil penelitiannya menunjukkan bahwa GTP lebih retentif ketika mukosa dan gigi tiruan dikeringkan dan saliva dihambat dengan atropin sulfat. Kedua hasil penelitian yang saling bertentangan tersebut sulit dijelaskan dalam penelitian ini karena kedua penelitian menggunakan cara yang berbeda dalam mengukur retensi GTP. ${ }^{18}$

Meshramkar dkk (2015) yang membenarkan hipotesis bahwa terdapat hubungan antara laju alir saliva dengan kecekatan GTP rahang atas. Penelitiannya mengevaluasi dan membandingkan efek penggunaan sialogogue (substansi peningkat laju alir saliva) topikal terhadap kecekatan atau retensi GTP rahang atas pada pasien terapi hipertensi yang mengalami hiposalivasi. Kelompok uji pada penelitiannya dibagi menjadi tiga grup yaitu retensi GTP rahang atas sebelum diaplikasikan sialogogue, retensi GTP rahang atas setelah diaplikasikan sialogogue secara langsung, dan retensi GTP rahang atas setelah 
Fakultas Kedokteran Gigi Universitas Andalas

Jalan Perintis Kemerdekaan No. 77 Padang, Sumatera Barat

Web: adj.fkg.unand.ac.id Email: adj@dent.unand.ac.id

diaplikasikan sialogogue selama satu minggu. Secara statistik hasil penelitiannya menunjukkan bahwa terdapat peningkatan retensi GTP rahang atas yang signifikan antara ketiga grup. ${ }^{19}$

\section{Hubungan Laju Alir dan Viskositas Saliva Dengan Tingkat Kecekatan GTP Rahang Bawah Pada Pasien Perawatan GTP RSGM Universitas Andalas}

Tabel 3. Hubungan Laju Alir Saliva Dengan Tingkat Kecekatan GTP Rahang Bawah Pada Pasien Perawatan GTP RSGM Universitas Andalas Tahun 2018-2019

\begin{tabular}{lccccccccc}
\hline \multirow{2}{*}{ Laju Alir Saliva } & \multicolumn{7}{c}{ Tingkat Kecekatan GTP rahang bawah } \\
\cline { 2 - 8 } & \multicolumn{2}{c}{ Minimum } & \multicolumn{2}{c}{ Sedang } & \multicolumn{2}{c}{ Maksimum } & \multicolumn{2}{c}{ Total } & \\
\cline { 2 - 8 } & $\mathrm{N}$ & $\%$ & $\mathrm{~N}$ & $\%$ & $\mathrm{~N}$ & $\%$ & $\mathrm{~N}$ & $\%$ & \\
\hline Hiposalivasi + rendah & 10 & 90,9 & 0 & 0 & 1 & 9,1 & 11 & 100 & \multirow{2}{*}{0,101} \\
Normal & 11 & 57,9 & 8 & 42,1 & 0 & 0 & 19 & 100 & \\
\hline Total & 21 & 70,0 & 8 & 26,7 & 1 & 3,3 & 30 & 100 & \\
\hline
\end{tabular}

Tabel 4. Hubungan Viskositas Saliva Dengan Tingkat Kecekatan GTP Rahang Bawah Pada Pasien Perawatan GTP RSGM Universitas Andalas Tahun 2018-2019

\begin{tabular}{lccccccccc}
\hline & \multicolumn{8}{c}{ Tingkat Kecekatan GTP rahang bawah } \\
\cline { 2 - 8 } Viskositas Saliva & \multicolumn{2}{c}{ Minimum } & \multicolumn{2}{c}{ Sedang } & \multicolumn{2}{c}{ Maksimum } & \multicolumn{2}{c}{ Total } & $p$ \\
\cline { 2 - 8 } & $\mathrm{N}$ & $\%$ & $\mathrm{~N}$ & $\%$ & $\mathrm{~N}$ & $\%$ & $\mathrm{~N}$ & $\%$ & \\
\hline Sangat tinggi + tinggi & 8 & 88,9 & 0 & 0 & 1 & 11,1 & 9 & 100 \\
Normal & 13 & 61,9 & 8 & 38,1 & 0 & 0 & 21 & 100 & 0,223 \\
\hline Total & 21 & 70,0 & 8 & 26,7 & 1 & 3,3 & 30 & 100 \\
\hline
\end{tabular}

Hasil penelitian menunjukkan bahwa hasil uji statistik hubungan laju alir saliva dengan tingkat kecekatan GTP rahang bawah pada pasien RSGM Universitas Andalas diperoleh nilai $p=0,101$ ( $p>0,05)$. Kesimpulan yang dapat ditarik dari data tersebut adalah tidak terdapat hubungan yang bermakna antara laju alir saliva dengan tingkat kecekatan GTP pada pasien RSGM Universitas Andalas. Hasil uji statistik untuk hubungan viskositas saliva dengan tingkat kecekatan GTP rahang atas pada pasien RSGM Universitas Andalas diperoleh nilai $p=0,223$ ( $p>0,05)$. Kesimpulan yang dapat ditarik dari data tersebut adalah tidak terdapat hubungan yang bermakna antara viskositas saliva dengan tingkat kecekatan GTP pada pasien RSGM Universitas Andalas. Hubungan laju alir dan viskositas saliva dengan tingkat kecekatan GTP pada pasien perawatan GTP RSGM Universitas Andalas dapat dilihat pada tabel 3 dan tabel 4.

Hubungan laju alir dan viskositas saliva dengan kecekatan GTP rahang bawah sulit dijelaskan karena minimnya penelitian yang dilakukan untuk melihat hubungan ini. Hal ini dikarenakan saliva lebih berperan penting terhadap GTP rahang atas dibandingkan GTP rahang bawah dalam meningkatkan retensi GTP. Hal ini didukung dengan teori yang menyatakan bahwa saliva lebih berperan terhadap GTP 
rahang atas karena faktor yang mempengaruhi retensi GTP yang berhubungan dengan saliva, seperti tegangan permukaan interfasial dan gaya kapilaritas lebih berfungsi secara maksimal pada GTP rahang atas. Hal ini juga bisa terjadi karena adanya saliva yang menggenang di sepanjang tepi GTP rahang bawah mengakibatkan kehilangan fungsi tegangan permukaan interfasial karena hilangnya liquid-air interface pada tepi GTP rahang bawah serta fungsi gaya tarik kapiler menjadi minimum dan terjadi dalam waktu yang singkat. Tegangan interfasial dan gaya kapilaritas merupakan salah satu faktor yang mempengaruhi retensi GTP. ${ }^{20}$

\section{SIMPULAN}

Kesimpulan dalam penelitian ini adalah laju alir saliva yang paling banyak ditemukan pada pasien perawatan GTP RSGM Universitas Andalas adalah laju alir saliva normal, sedangkan viskositas saliva yang paling banyak ditemukan pada pasien perawatan GTP RSGM Universitas Andalas adalah viskositas saliva normal. Tingkat kecekatan GTP rahang atas yang paling banyak ditemukan pada pasien perawatan GTP RSGM Universitas Andalas adalah tingkat kecekatan maksimum sedangkan tingkat kecekatan GTP rahang bawah yang paling banyak ditemukan pada pasien RSGM Universitas Andalas adalah tingkat kecekatan minimum. Laju alir dan viskositas saliva berhubungan dengan tingkat kecekatan GTP rahang atas dan laju alir dan viskositas saliva tidak berhubungan dengan tingkat kecekatan GTP rahang bawah.

\section{KEPUSTAKAAN}

1. Budiono, Endang S, Diyah F., Pengembangan instrumen penilaian kinerja keterampilan mencetak rahang bergigi teknik mukostatik. Journal of Educational Research and Evaluation. 2016.

2. Departemen Kesehatan RI. Laporan Nasional Riskesdas 2018, 2018. [diakses dari http://depkes.go.id tanggal 30 Maret 2019].

3. Departemen Kesehatan RI. Laporan Hasil Riset Kesehatan Dasar (Riskesdas) tahun 2013, 2013. [diakses dari http://depkes.go.id tanggal 25 Februari 2019].

4. Nooji, D., Post insertion problems and management in complete denture patients. KVG Dental College \& Hospital. 2017.

5. Pathmashri VP, Abirami., A review on denture stomatitis. Pharm. Sci. \& Res, 2016; 8(8): 875-877.

6. Chandu GS, MN Hombesh, Management of xerostomia and hyposalivation in complete denture patients. Indian J Stomatol, 2011; 2(4): 263-66.

7. Veeraiyan DN., Textbook of Prosthodontics. 2nd ed. New Delhi: Jaypee Brothers Medical Publishers (P) Ltd. 2017.

8. Taqa A.A., et al., Evaluation of physical and chemical properties of saliva on retention of complete denture (In vitro study). International Journal of Dentistry Research. 2018; 3(4): 50-54.

9. Singh B.P., et al., Effect of sociodemographic variables on complete denture satisfication. 2012; 4: 43-51.

10. Gholami N., et al., Effect of Stress, Anxiety, and Depression on Unstimulated Salivary Flow Rate \& Xerostomia. J. Dent. Res. Dent Clin. Dent. Prospects. 2017; 11(4): 247-252. 
Fakultas Kedokteran Gigi Universitas Andalas

Jalan Perintis Kemerdekaan No. 77 Padang, Sumatera Barat

Web: adj.fkg.unand.ac.id Email: adj@dent.unand.ac.id

11. Kasuma, N., Fisiologi dan Patologi Saliva. Andalas University Press. 2015.

12. Nassar M., et al., Age-related change in salivary biomarkers. Journal of Dental Sciences, 2013; (9): 85-90.

13. Sikander I., et al., Frequency of Short-Term Post-Insertion Complaints in Conventional Complete Denture Wearers Treated by Undergraduate Students. Pakistan Oral \& Dental Journal. 2017: vol. 36 (4).

14. Limpuangthip N., Tewarit S., Mansuang A., Impact of Denture Retention and Stability on Oral Health-Related Quality of Life, General Health, and Happiness in Elderly Thais. Current Gerontology and Geriatrics Research. 2019.

15. Sachdeva S, Rana N, Rizwana M, Eram P., Role of Saliva in Complete Dentures: An overview. Annals of Denta Specialty. 2014L vol. 2(2).

16. Gupta R., Luthra R.P., Shikha G., A comparative analysis of retention of mandibular denture bases in patient with resorbed ridges with or without sublingual extension - an in vivo study. International Journal of Advanced Research, 2016; 4(11): 1920-1929.

17. Srivastava V., et al., The neutral zone: Concept and technique. Journal of Orofacial Research, 2012; 2(1): $42-47$.

18. Shekhar A., et al., A compatarive analysis of salivary factors and maxillary denture retention in different arch forms: An in vivo study. J Indian Prosthodont Soc, 2018, pp. 53-60.

19. Meshramkar R., et al., Influence of Sialogogue on complete denture retentionin patients on antihypertensive drug therapy. International Journal of Pharmaceutical Research and Applications. 2015; 2(2): 11-16.

20. Jacob S.A dan Anoop G., Saliva in Prosthodontic Therapy - All You Need to Know. Research and Reviews: Journal of Dental Sciences. 2013: vol. 1(1). 